Ann. Biol. anim. Bioch. Biophys., I976, 16 (2), 235-243.

\title{
GONADOTROPHIN RELEASING HORMONE THERAPY
}

\author{
C. H. MORTIMER, A. S. MCNEILLY and G. M. BESSER \\ The Medical Professorial Unit and Department of Chemical Pathology, \\ Saint Bartholomere's Hospital, London, EC1 7BE
}

\section{SUMMARY}

In view of the high proportion of patients with demonstrable hypothalamic or pituitary disease who responded to a single intravenous bolus injection of $\mathrm{Gn}-\mathrm{RH}$ it was hoped that repeated administration (500 $\mathrm{gg} 8$ hourly) of the decapeptide would prove to be of therapeutic value.

Treated prepubertal males (craniopharyngioma, isolated growth hormone deficiency) showed an improvement in pubic hair, a marked increase in the frequency of erections and testicular size increased.

Nine adult males with hypothalamic or pituitary disease have been treated; in all these patients, a rapid return of potency has been observed between 2 and 17 days after starting therapy. In four of them treated for I2-18 months potency has been well maintained. In addition, spermatogenesis was induced within 7 to 26 weeks of starting therapy. FSH levels have fallen as the sperm count has risen ("inhibin ") although LH levels have been little altered. One patient's wife is now pregnant.

Female patients with anorexia nervosa (clomiphene unresponsive) and documented amenorrhea for 5-7 years, have been treated with $\mathrm{Gn}-\mathrm{RH}$ resulting in ovulation and mensturation. The addition of $\mathrm{HCG}_{4} 500$ units on day $\mathrm{I}_{4}$ in one patient also resulted in pregnancy.

Gn-RH may be of value in the treatment of male and female infertility.

\section{INTRODUCTION}

Following the work of McCANN I962, McCANn and Dhariwal I966, it was suggested that hypothalamic regulation of pituitary gonadotrophin secretion was by means of two separate releasing hormones for luteinising hormone ( $\mathrm{LH}$ ) and follicle stimulating hormone (FSH). However, SchalLy et al. (I97I) were able to isolate only a single gonadotrophin releasing hormone (Gn-RH) from porcine hypothalami. Administration of this decapeptide results in both $\mathrm{LH}$ and $\mathrm{FSH}$ release and therefore has left unresolved the identity of FSH-RH, if indeed it exists at all in man.

When the synthetic material became available many centres including our own investigated its properties. It was shown that the decapeptide released both $\mathrm{LH}$ and 
FSH in a dose related manner when 25 to $500 \mu \mathrm{g}$ was given as an intravenous bolus (BESSER et al., I972). Subsequently a standard roo $\mu \mathrm{g}$ test was devised sampling for $\mathrm{LH}$ and FSH before and 20 and 60 minutes after the injection of Gn-RH. This test was then applied to 155 patients with hypothalamic-pituitary-gonadal disease. The results showed that although $88 \mathrm{p}$. Ioo were clinically hypogonadal when tested initially, only ro $\mathrm{p}$. Ioo of the patients had an absent response to the releasing hormone. It was also evident that this test could not distinguish between hypothalamic and pituitary disease since identical responses could be obtained in either group, although primary gonadal failure resulted in an exaggerated response (MORTIMER et al., 1973). In view of the large number of patients with demonstrable hypothalamic or pituitary disease who did respond it was hoped that repeated administration of the decapeptide would prove to be of therapeutic value.

Studies of the time course of action of Ioo $\mu \mathrm{g}$ Gn-RH given by intravenous, intramuscular or subcutaneous routes showed that they were equally effective in elevating $\mathrm{LH}$ for 5-7 hours and FSH for 3-5 hours (MORTIMER et al., I974 a). Intranasal administration unfortunately was not particularly effective since at least $2 \mathrm{mg}$ had to be given by this route to produce the same effect as Ioo $\mu \mathrm{g}$ by the other routes (LoNDON et al, I973). In our studies, therefore, self administration of $\mathrm{Gn}-\mathrm{RH}$ by the subcutaneous route was chosen and in view of the time course of gonadotrophin release injections were given 8 hourly. A dose of $500 \mu \mathrm{g}$ was used since earlier studies had shown that patients with isolated gonadotrophin deficiency' might fail to respond to roo $\mu \mathrm{g}$, but this could be improved by increasing the dose (MARSHALL et al., I972). Patients who had previously received gonadai steroids or intramuscular gonadotrophin treatment were taken off all therapy for at least 4 months prior to Gn-RH administration.

\section{PREPUBERTAL MALES : PUBERTY AND POTENCY}

Initially five prepubertal patients were treated aged $\mathrm{I}_{4}$ to 22 years. Of these, four had craniopharyngiomas and one isolated growth hormone deficiency. All were clomiphene negative except one (craniopharyngioma). Treatment resulted in progressive increases in both gonadotrophins with the FSH response being greater initially than that of LH. This prepubertal pattern of response (FRANCHIMONT et al., I974) was later reversed becoming adult in type. (fig. I). Of the five patients, two were still growing with intramuscular growth hormone therapy and so Gn-RH treatment was discontinued after 4 weeks since it was considered undesirable to induce puberty while they still had growth potential. However, therapy was continued in two of them (craniopharyngioma, isolated growth hormone deficiency). Before treatment one had pre-adolescent genitalia at Stage I puberty (TANNER, I958). After 8 weeks of treatment this patient showed an increase in spontaneous erections with Stage 3 pubic hair. The other was Stage 3 before therapy but after nine weeks showed an improvement in pubic hair with a marked increase in the frequency of erections. Testicular size increased from 4-6 $\mathrm{ml}$ before treatment to $6-\mathrm{I} 2 \mathrm{ml}$ after 20 weeks in these patients. 


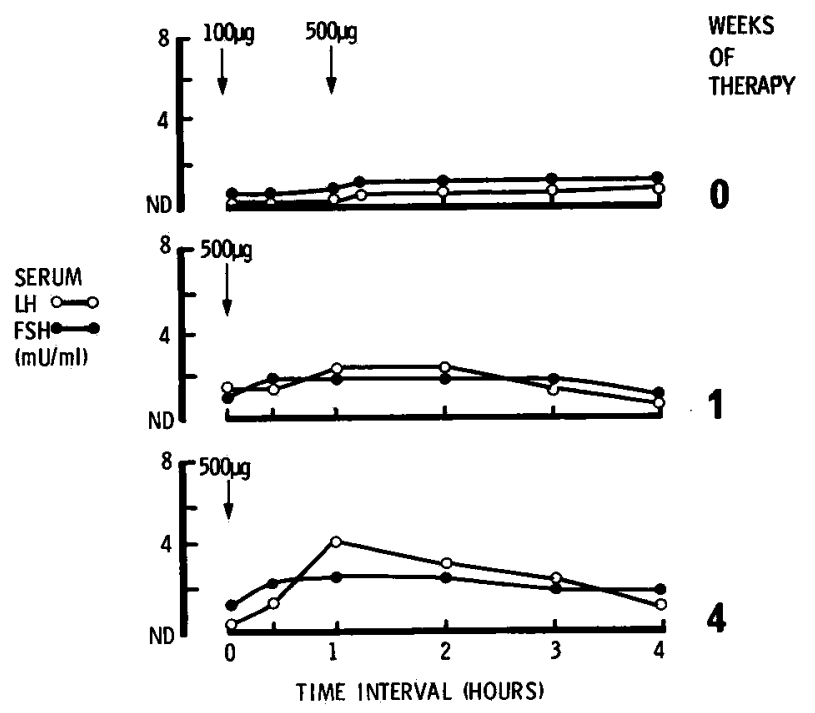

FIG. I. - Sevum LH O and FSH - responses to Gn-RH in a prepubertal male aged 14 years with a craniopharyngiomx

\section{ADULT MALES : POTENCY AND SPERMATOGENESIS}

Nine adult males with hypothalamic or pituitary disease have been treated. Of these, six had isolated gonadotrophin deficiency; one craniopharyngioma; one acromegaly treated with external pituitary irradiation and one a diffuse hypothalamic tumour of unknown origin. In all patients there was an increase in potency between 2 and $\mathrm{I} 7$ days after starting therapy, despite testosterone levels below the normal adult male range in all but two. The rapid return of potency in these patients despite levels of testosterone normally associated with impotence suggests that these behavioural effects may not be entirely androgen mediated. It is of interest that Moss and McCANn (I973), PFAFF (I973) have reported an increase in the number of lordotic responses in ovariectomised and hypophysectomised rats following subcutaneous administration of the releasing hormone. The role of $\mathrm{Gn}-\mathrm{RH}$ in psychogenic impotence remains to be defined and we await the results of a double blind crossover trial being carried out in conjunction with Professor R. HALL and co-workers in Newcastle.

Four adult males have been treated for I2-I 8 months and potency has been well maintained. In addition, spermatogenesis was induced within 7 to 26 weeks of starting therapy. Two with " isolated " gonadotrophin deficiency and the craniopharyngioma patient had low or undetectable basal gonadotrophins, and all were clomiphene unresponsive. During initial therapy the prepubertal type of gonadotrophin response to $\mathrm{Gn}-\mathrm{RH}$ was seen although later as in the prepubertal boys this pattern became adult in type. During therapy the maximum LH levels following a therapeutic $500 \mu \mathrm{g}$ dose of Gn-RH showed no definite pattern. However, in all three patients the maximum FSH response began to decline before spermatazoa were seen 
on seminal analysis and showed a progressive fall into the normal basal male range throughout therapy (fig. 2).

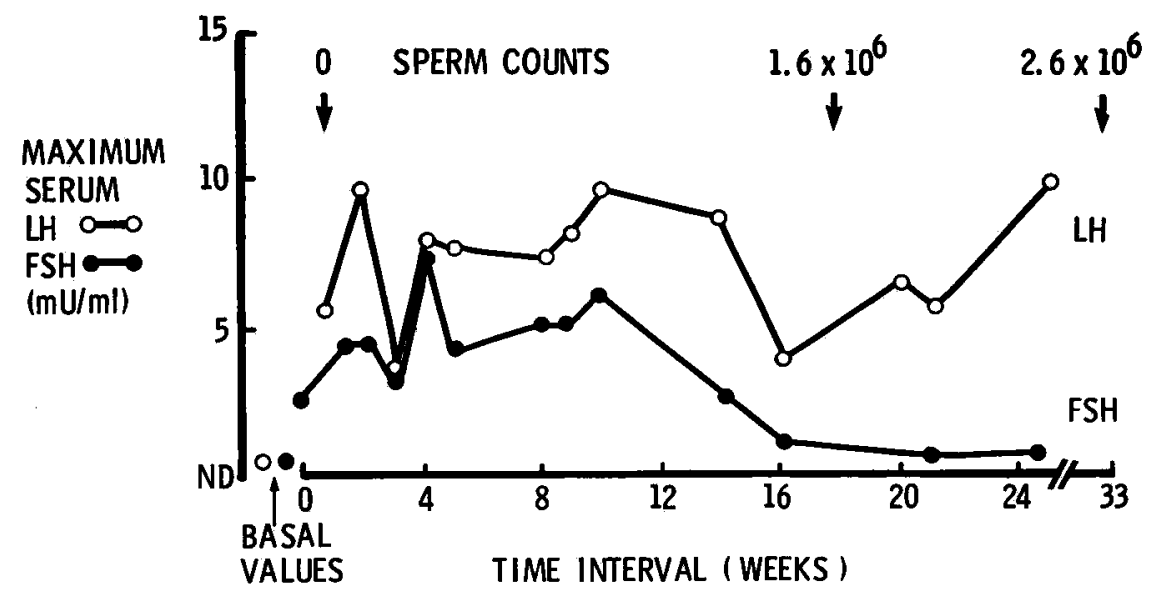

FIG. 2. - Maximum serum LH O and FSH • responses to .j00 $\mu \mathrm{g}$ Gn-RH subcutaneously in a man with isolated gonadotrophin deficiency

The gonadotrophin results in the patient with acromegaly were different since he had an elevated basal FSH level of $17.3 \mathrm{mU} / \mathrm{ml}$ (normal range less than 0.2 to $5.9 \mathrm{mU} / \mathrm{ml}, \mathrm{MRC}$ standard 68/39) although the basal $\mathrm{LH}$ was normal at $3.8 \mathrm{mU} / \mathrm{ml}$ (normal range less than 0.4 to $6 \mathrm{mU} / \mathrm{ml}$, MRC standard 68/40). He had much reduced potency, low plasma testosterone and was azoospermic. When tested with roo $\mu \mathrm{g}$ Gn- $\mathrm{RH}$ he had a normal LH response but an exggerated FSH rise. The maximum FSH response at the beginning of treatment showed levels greater than $50 \mathrm{mU} / \mathrm{ml}$ but fell progressively before and following the appearance of spermatozoa (fig. 3). During treatment in these four patients total sperm counts have risen from zero (or 600.000 dead spermatozoa in one patient who had received human chorionic gonadotrophin 4 months prior to the study) to maximum levels of 7.8 and 60.8 million (isolated gonadotrophin deficient patients), $\mathrm{I}_{4} 6$ million (acromegalic) and 432 million (craniopharyngioma) with a motility of 40-70 p. I00. This was accompanied by an increase in testicular volume from $\mathrm{r}-3 \mathrm{mls}$ before to between 8 - $5 \mathrm{mls}$ after 52 weeks of treatment. In all patients in whom spermatogenesis has occurred FSH levels have fallen as the sperm count has risen although LH levels have been little altered. This suggests that a factor (inhibin) has been released which selectively impairs FSH secretion. A1so, since circulating $\mathrm{Gn}-\mathrm{RH}$ levels were maintained by repeated subcutaneous injection it would seem that the site of action of inhibin is primarily at the pituitary level. It is also clear that pituitary responsiveness in male subjects may be modified by circulating substances other than testosterone or oestrogen (plasma I $^{\beta} \beta$-oestradiol levels were within the normal male range throughout therapy except on three isolated occasions).

Following one year of therapy the acromegalic patient was treated with bromocriptine in order to suppress growth hormone secretion (THORNER et al., I974). Gn-RH therapy was continued and the total sperm maintained around I30 million. This patient's wife is now 3 months pregnant. 
Gn-RH therapy has been used also to treat patients with oligo-or azoospermia. (ZARATE et al., I973). Treatment with $500 \mu \mathrm{g}$ subcutaneously, twice daily for 6 months resulted in an increase from a total count of I-5 million basally to Io million. The count then fell despite continued therapy. Three of their patients showed no significant improvment although all had an increase in motility. It remains to be seen if Gn-RH therapy is of benefit in patients with primary gonadal dysfunction resulting in infertility.

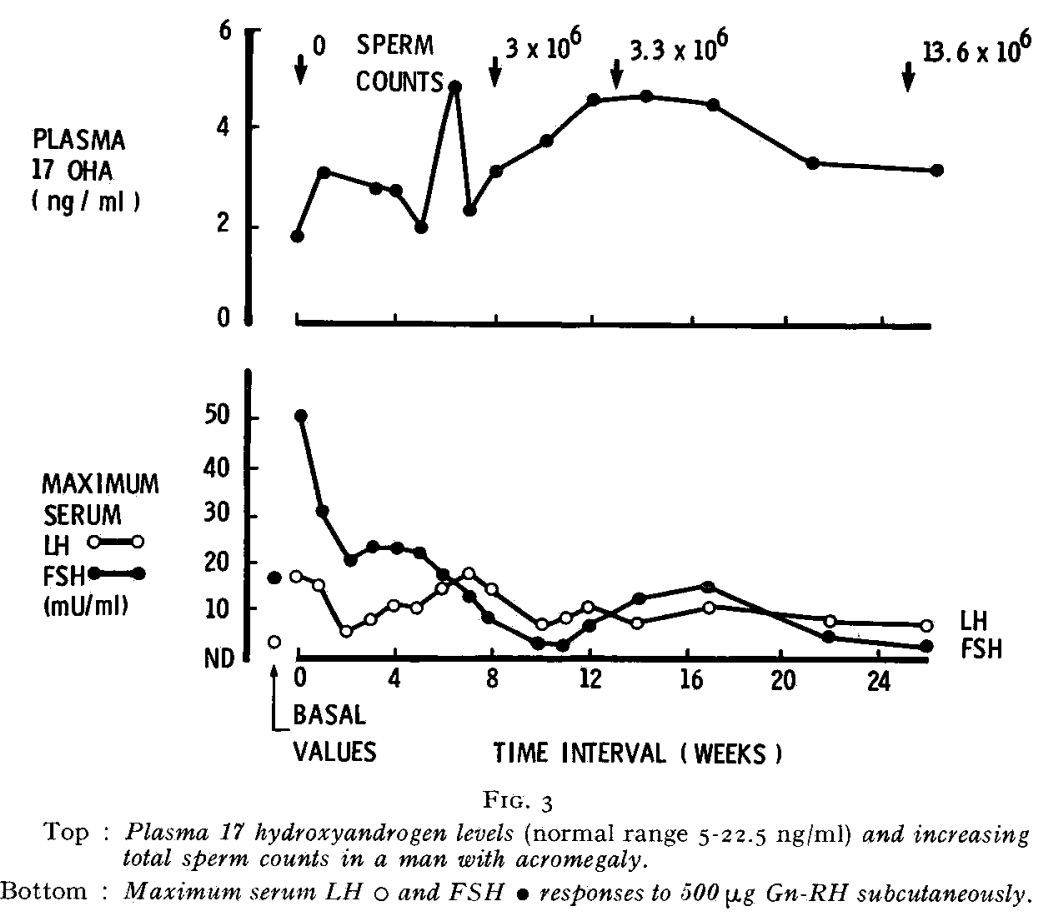

\section{FEMALES : OVARIAN STEROIDOGENESIS, OVULATION AND MENSTRUATION}

In 1972, AKANDE et al., reported a series of studies in 8 patients with secondary amenorrhoea although the diagnosis was not recorded in all of them. However, although a rise in gonadotrophins was observed ovulation occurred in only one who had ovulated spontaneously while basal sampling was being carried out prior to the study. Other studies were subsequently reported (KELLER I973; BRECKWOLDT et al., I974) but the value of $\mathrm{Gn}-\mathrm{RH}$ therapy for ovulation induction remained undecided. More recent studies have produced ovulation in 2 of 16 women with secondary amenorrhoea following depot-medroxyprogesterone acetate or chlormadinone therapy for contraceptive purposes (ZANARTU et al., I974). However, the low success rate achieved suggests that the optimal regimen for reliable ovulation induction remains to be found. 
In our own study, we have treated four patients aged between I9 and 29 years with anorexia nervosa and documented amenorrhoea for 5-7 years. These patients were either at their ideal body weight or between 3.5 and $5.8 \mathrm{kgs}$ below this, and each was clomiphene unresponsive. Basal total urinary oestrogens were between 4 and $17 \mu \mathrm{g} / 24$ hours measured fluorimetrically (BROWN et al., r968). Initial therapy with $500 \mu \mathrm{g} \mathrm{Gn}-\mathrm{RH}$ was given by subcutaneous injection 8 hourly for 7 days, then stopped and restarted on days I2-I4. During this study samples for serum gonadotrophins were collected ro hours after the last dose of releasing hormone given the previous night. Basal serum gonadotrophins were low or absent in all these patients although during therapy these was a rise with more LH than FSH secreted. During the first seven days urinary oestrogens rose to a maximum between 62 and $135 \mu \mathrm{g} / 24$ hrs (normal mid-cycle range between 30 and $\mathrm{I} 20 \mu \mathrm{g} / 24 \mathrm{hrs}$ ). When therapy was discontinued after 7 days gonadotrophins became low or undetectable with a fall in urinary oestrogens. There was then a further rise when treatment was restarted between days I2-I4. In all subjects there was a rise in 24 hours total urinary oestrogens between days 18 and 28 despite being off therapy preceeded by a rise in basal serum gonadotrophins. These results therefore indicate that the patients had adequate pituitary LH
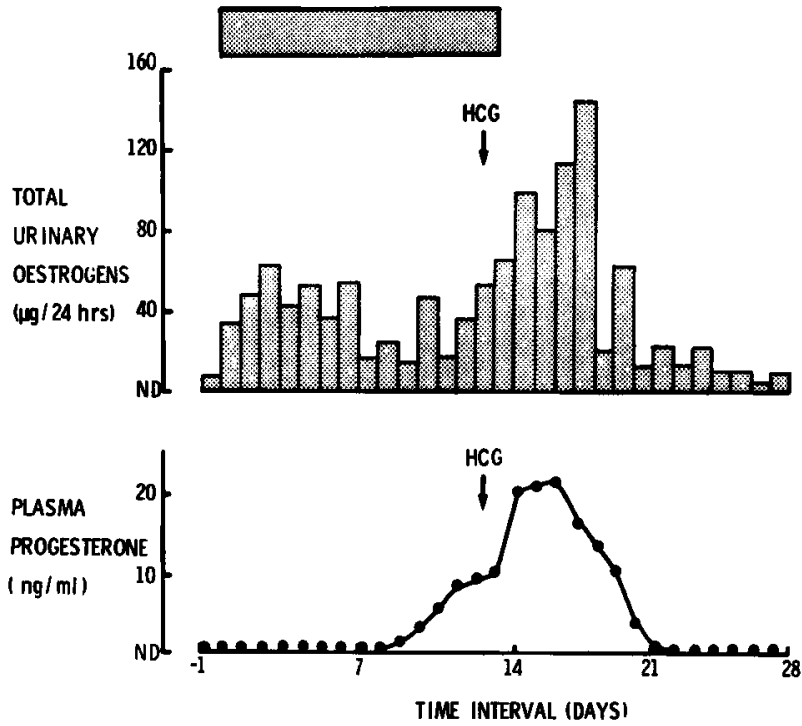

FIG. 4. - Total 24 hrs urinary oestrogen and plasma progesterone responses to Gn-RH .500 $\mu_{\mathrm{g}} 8$ hourly subcutaneously in a woman with anorexia nervosa

and FSH reserve although the release of the gonadotrophins was impaired while off therapy due to a persistent deficiency of endogenous Gn-RH. Therapy resulted in rises in total 24 hour urinary oestrogens (and plasma oestradiol) to levels comparable to those seen in normal cycles. The occurrence of spontaneous release of gonadotrophins between days $18-28$ despite being off treatment indicates that there had been positive feedback of the rise in circulating oestrogens at the hypothalamicpituitary level. Following this treatment one patient menstruated for the first time in 6 years, although there was no biochemical evidence of ovulation in any of the 4 
patients. Two patients were retested after I2-I4 weeks off therapy with clomiphene and both now showed a rise in urinary oestrogens followed by a rise in urinary pregnanediol indicative of ovulation. Both patients also menstruated. The other two instead of clomiphene received a further course of Gn-RH $500 \mu \mathrm{g} 8$ hourly except this was continued for I4 days, at which time an injection of 4.500 units of $\mathrm{HCG}$ was given intramuscularly (fig. 4). In both patients there was a rise in urinary oestrogens together with a rise in plasma progesterone from less than $\mathrm{I} \mathrm{ng} / \mathrm{ml}$ to 6.4 and $9.9 \mathrm{ng} / \mathrm{ml}$ on day $\mathrm{I} 4$ before $\mathrm{HCG}$ was given. Both patients later menstruated.

Further studies involving the administration of $\mathrm{Gn}-\mathrm{RH} 500 \mu \mathrm{g} 8$ hourly for 28 days has resulted in ovulation (as determined by a rise in urinary pregnanediol from undetectable to $6.5 \mathrm{mg} / 24 \mathrm{hrs}$ ) and menstruation. The addition of $\mathrm{HCG} 4.500$ units on day 14 in one patient resulted in ovulation and pregnancy. Continuous therapy initially for $I$ month and then for a further 4 months in a patient with isolated gonadotrophin deficiency has resulted in a cyclical increase in 24 hour total urinary oestrogens from I to $30 \mu \mathrm{g} / 24 \mathrm{hrs}$ and increase in breast size although ovulation and menstruation have not yet occurred.

It would appear therefore that Gn-RH therapy will result in ovarian steroidogenesis and ovulation. This may be followed by menstruation although no female has reported the increase in libido noted by the men. Since Gn-RH therapy for ovulation induction results in the production of oestrogen and progesterone levels normally seen during the menstrual cycle, it is hoped that hyperstimulation of the ovary and multiple births will be avoided.

\section{CONCLUSION}

Studies with $\mathrm{Gn}-\mathrm{RH}$ indicate that the single decapeptide is capable of promoting synthesis as well as the differential release of LH and FSH by the modulation of pituitary responsiveness by gonadal steroids and inhibin. It may be of value in the treatment of male and female infertility and suggests that although a distinct FSHRH may yet exist in man, it is not essential for these events to occur. Future studies involving depot preparations and analogues more resistant to enzymatic degradation may further widen the scope of Gn-RH therapy.

Symposium Gn-RH, Tours, 25 mars 1975.

\section{ACKNOWLEDGEMENTS}

We are grateful to the Editor of the British Medical Journal for permission to reproduce figures I, 2, 3 (from MortimeR et al., I974 b) ; Hoechst (U. K.) for suppling the synthetic Gn-RH and the Medical Research Council, Peel Medical Research Trust and the Joint Research Board, Saint Bartholomew's Hospital for their financial support. 


\author{
RÉSUMÉ \\ TRAITEMENT PAR L'HORMONE DE LIBÉRATION \\ DES GONADOTROPINES ((Gn-RH)
}

Puisqu'une proportion élevée (88 p. Ioo) de patients avec des troubles hypothalamiques ou hypophysaires répondent au Gn-RH, il était possible d'espérer que des administrations répétées (500 $\mu \mathrm{g}$ toutes les 8 heures) du décapeptide auraient une certaine valeur thérapeutique.

Quelques adolescents mâles prépubères traités avec le Gn-RH ont effectivement montré une augmentation importante de la fréquence d'érection et de la taille testiculaire.

De même, 9 patients mâles adultes souffrant de troubles hypothalamiques ou hypophysaires ont tous montré un retour rapide de la puissance entre $\mathbf{2} 2$ et $\mathrm{I} 7$ jours après le début du traitement au Gn-RH. Celle-ci s'est maintenue chez quatre d'entre eux traités pendant I 2 à I 8 mois. En outre, la spermatogenèse a été induite 7 à 26 semaines après le début du traitement. Les niveaux plasmatiques de FSH ont diminué lorsque le nombre de spermatozoïdes s'est élevé dans l'éjaculat ("inhibine ") bien que les niveaux de LH n'aient pas été modifiés. La femme de l'un des patients est actuellement enceinte.

Des femmes avec anorexie nerveuse et aménorrhée depuis 5-7 ans et ne répondant pas à un traitement au clomiphène ont reçu des injections de Gn-RH pendant des durées variables jusqu'à 28 jours. L'ovulation et la menstruation ont été obtenues. L'injection supplémentaire de 4500 unités de HCG le $\mathrm{I}_{4}{ }^{\mathrm{e}}$ jour chez une patiente a permis l'installation d'une grossesse.

Ainsi, le Gn-RH peut être utile dans le traitement de la stérilité mâle ou femelle.

\title{
REFERENCES
}

Akande E. O., Carr P. J., Dutton A., Bonnar J., Corker C. S., McKinnon P. C. B., Robinson D., 1972. Effect of synthetic gonadotrophin-releasing hormone in secondary amenorrhoea. Lancet, 2 , II2-II 6 .

Besser G. M., McNeilly A. S., Anderson D. C., Marshall J. C., Harsoulis P., Hall R., Ormston B. J., Alexander L., Collins W. P., ig72. Hormonal responses to synthetic luteinizing hormone and follicle stimulating hormone releasing hormone in man. Brit. Med., J., 3, 267-27.I.

Brechwoldt M., Czygan P. J., Lehman F., Bettendorf G., I974. Synthetic LH-RH as a therapeutic agent. Acta Endocr., 75, 209-220.

Brown J. B., Mcleod S. C., MeNaughton C., Smith M. A., Smyth B., ig68. A rapid method for estimating oestrogens in urine using a semi-automatic extractor. N. Endocr., 42, 5-I5.

Franchimont P., Becker H., Ernould Ch., Thys Ch., Demoulin A., Bourguignon J. P. LEgros J. L., VALCHE. J. C., I974. The effect of hypothalamic luteinizing hormone releasing hormone (LH-RH) on plasma gonadotrophin levels in normal subjects. Clin. Endocr., 3, 27-39.

London D. R., Butt W. R., Lynch S. S., Marshall J. C., Owusu S., Robinson W. R., StephensoN J. M., I973. Hormonal responses to intranasal luteinizing hormone releasing hormone. J. Clin. Endocr. Metab., 37, 829-831.

Marshall J. C., Harsoulis P., Anderson D. C., McNeilly A. S., Besser G. M., Hall R., 1972. Isolated pituitary gonadotrophin deficiency : gonadotrophin secretion after synthetic luteinizing hormone and follicle stimulating hormone releasing hormone. Brit. Med. J., 4, 643-645.

McCann S. M., 1962. A hypothalamic luteinizing hormone releasing factor. Am. J. Physiol, 202, 395-400.

McCann S. M., Dhariwal A. P. S., I966. Hypothalamic releasing factors and the neurovascular link between the brain and the anterior pituitary. In Neuroendocrinology, MARTINi L., Ganong W. F. Ed., Acad. Press N. Y., 1, 26r-296.

Mortimer C. H., Besser G. M., Hook J., McNeilly A. S., i974 a. Intravenous, intramuscular, subcutaneous and intranasal administration of LH/FSH-RH. The duration of effect and occurrence of asynchronous pulsatile release of LH and FSH. Clin. Endocr., 3, 19-25.

Mortimer C. H., Besser G. M., McNeilly a. S., Marshall J. C., Harsoulis P., Tunbridge W. M. G., Gomez-PAN A., Hall R., r973. Luteinizing hormone and follicle stimulating hormone releasing hormone test in patients with hypothalamic pituitary gonadal dysfunction. Brit. Med. J., 4, 73-77. 
Mortimer C. H., McNeilly A. S., Murray M. A. F., Fisher R. A., Besser G. M., I974 b. Gonadotrophin-releasing hormone therapy in hypogonadal males with hypothalamic or pituitary dysfunction. Brit. Med. J., 617-621.

Moss R. L., McCANN S. M., I973. Induction of mating behavior in rats by luteinizing-releasing factor. Science, 181, 177-179.

PfafF D. W., r973. Luteinizing hormone releasing factor potentiates lordosis behavior in hypophysectomized ovariectomized female rats. Science, 182, I I 48-II49.

Schally A. V., Arimura a., Baba Y., Nair R. M. G., Matsuo H., Redding T. W., Debeljuk L., White W. F., I97I. Isolation and properties of the FSH and $\mathrm{LH}$ releasing hormone. Biochem. Biophys. Res. Comm., 43, 393-399.

TANNER J. M., I958. The evaluation of physical growth and development. In Modern trends in paedia. trics, Holzel A., Tizard J. P. M. Ed., London Butterworth (second séries).

Thorner M. O., Chait A., Aitken M., Benker G., Bloom S. R., Mortimer C. H., Sanders, P., Stuart Mason A., Besser G. M., 1975. Bromocryptine treatment of acromegaly. Brit. Med.J., 1 , 299-303.

Zanartu J., Dabancens A., Rodriguez-Bravo R., Schally A. V., 1974. Induction of ovulation with synthetic gonadotrophin-releasing hormone in women with constant anovulation induced by contraceptive steroids. Brit. Med. J., 605-608.

Zarate A., Valdes-Vallina F., Gonzalez A., Perez-Ubierna C., Canales E. S., Schally A. V., 1973. Therapeutic effect of synthetic luteinizing hormone releasing hormone (LH-RH) in male infertility due to idiopathic azoospermia and oligospermia. Fertil. Steril., 24, 485-486. 